\title{
PRODUCTION IMPROVEMENT STRATEGY OF COMMUNITY-BASED SALT IN PALU BAY
}

\author{
Rustam Abd. Rauf ${ }^{1)}$, Asriani Hasanuddin ${ }^{2)}$, Rosedi ${ }^{3)}$ \\ ${ }^{1)}$ Lecturer and Researcher at Department of Agribusiness Faculty of Agriculture. University of Tadulako. Palu. \\ e-mail: rustam.abdrauf@ gmail.com \\ ${ }^{2)}$ Lecturer and Researcher at Faculty of Animal Husbandry and fisheries. University of Tadulako. Palu. \\ ${ }^{3)}$ Department of Agriculture Fisheries and Marine Palu. Central Sulawesi.
}

\begin{abstract}
Palu is one of the main areas that have regional salinity and the management is still using the traditional way. Internal factors of inner salt farmers and external factors affecting the production of folk salt in the city of Palu. This study aims to (1) identify the internal factors that become strengths and weaknesses in increased production of community-based salt at Palu bay; (2) identify external factors that became opportunities and threats in the increased production of community-based salt in Palu Bay; (3) define an alternative strategies for improving folk's salt production in Palu bay. SWOT analysis results indicate that the appropriate strategy in improving the community-based salt production in Palu bay is in the position of the quadrant I SO strategy (Strength-Opportunities). This strategy is implemented by the program: (1) Maximizing production by utilizing the available resources; (2) Increasing the salt farmer mastery of science that accompanied the adoption of appropriate technological innovation; and (3) Increasing capacity in marketing management and build a broader partnership. The results of the analysis obtained the best strategy QSPM the 2nd program "Improvement of salt farmer mastery of science that accompanied the adoption of technological innovations.
\end{abstract}

Key Words : Palu bay, QSPM, salt people and SWOT.

\section{INTRODUCTION}

Indonesia is an archipelago country that has abundant potential resources, Indonesia is demanded to managing marine and fishery resources effectively and sustainably for the welfare of the community. One of the potential in marine and fisheries in Indonesia is the coastal area. Wealth coastal region has a special attraction for the various parties to take advantage of its resources and encourage various agencies to regulate their use. Coastal resources are natural resources, resource assisted/artificial and environmental services contained in the coastal areas. According to Kusumaningrum Arta (2013), the program needed to use resources that have an impact on coastal communities.
The coastal area of Indonesia has a major role to improve the welfare of the community, one of the commodities from the coastal area is salt. The raw materials are very abundant because Indonesia located at the equator area with a high intensity of solar radiation, long coastline, as well as the long dry season which is a contributing factor to produce salt production.

Salt is a strategic commodity as industrial raw materials and food stuffs which is needed by almost all societies, but nowadays the lives of salt farmers in various regions in Indonesia, faced with a difficult situation. Many farmers can't survive with its business choice, and some have left the business and moved to pursue other livelihoods. According Kurniasari (2014), social groups of small-scale 
farmers (salt farmer) status is considered lower than other groups when Indonesia was known as a maritime nation.

Palu is one area that has a salting area and its management in the traditional way. Based on data from the Department of Agriculture, Forestry and Marine Palu (2015), salting in Palu bay occupies a land area of 18 hectares, it is very unfortunate if the salting area is not kept its existence and endeavor to increase its production through a variety of efforts to formulating the right strategy. The existence of the local salt business in the city of Palu face a variety of threats and vulnerabilities to continue its existence, problems of quality and quantity of production seems to still need to get extra attention and efforts to a better handling. Internal factors of inner salt farmers and external factors affecting the production of salt business people in the city of Palu. Along with the plan of the government through the Ministry of Maritime Affairs and Fisheries for selfsufficiency in salt, then the demands for increased production is an absolute must, therefore, needs an appropriate strategy to achieve this goal so that the management of salt people in the city of Palu can be conducted properly and maximum by salt farmers in order to improve their welfare.

The purpose of this study were (1) to identify the internal factors that became both the strengths and weaknesses in increased production of communitybased salt at Palu bay; (2) to identify the external factors that became opportunities and threats in the increased production of community-based salt in Palu bay; (3) determine an alternative strategies to improve the salt production of communitybased salt in Palu bay.

\section{METHODOLOGY}

This research is descriptive research was to gather information, find internal environmental factors (strengths and weaknesses) and external environmental factors (opportunities and threats). These factors were studied and analyzed by the method of SWOT analysis (Strengths, Weakness, Opportunities and Threats) to produce a strategy to support the improvement of community-based salt production.

Locations were selected intentionally (purposively), with consideration in Palu there is only one area that has a production area of community-based salt, which is in the gulf of Palu, with a land area of 18 hectares (Marine and Fisheries Department Palu, 2015). This study was conducted over three (3) months, ie October s/d December 2015. The samples were conducted by the method solving, from a population of 160 people and with an error tolerance limit of $15 \%$, the obtained samples of 35 people with random sampling techniques and to obtain additional information, taken five respondents support from the parties involved.

The analysis technique used in this study include:

1. SWOT analysis, this analysis is used to identify internal and external factors salt activities of the people, as well as to formulate strategies to increase future production.

2. Analysis of Quantitative Strategic Planning Matrix (QSPM), QSPM is a tool used to evaluate alternative strategies objectively selection based on the key success factors of internalexternal been identified previously

\section{RESULTS AND DISCUSSIONS}

\section{Internal Evaluation Strategy Factors (IFAS).}

\section{Strengths:}

Salt Farmer Experience. The Experience of the salt farmers is one of the factors that determine the smoothness of the activities that will be implemented. The experience of the salt farmers according to Widiarto (2013), is one of the major forces that are owned by the salt farmers in conducting salting. One's skills in business is largely determined by the experience he 
has experienced, the longer a person works the more experience gained. According to Rahman et al. (2014), that by only focusing on one job, then indirectly a salt farmers will have the tenacity and diligence in his work, which then form its membership.

Salt farmers in processing the salt in Palu bay can be categorized experienced. Through the interviews with respondents farmers can be seen that of the 35 respondents who are generally salt farmers, on average, have had experience doing community-based salt business for 10 to 25 years. The experience becomes its own power for the people's to increase the salt production in the Palu bay.

The Availability of Abundant Raw Materials. Sea water as the main raw material in the manufacture of salt is abundant in the Gulf of Palu. The distance between the pond for the manufacture of salt in the coastal area is also very close to the sea which is the main source of raw material in the manufacture of salt. Utilization of material that has been available in nature which also obtained easily is a strength that is very supportive in the process of maximizing the production of salt people. Availability of raw materials in the location of research strongly supports the production process in a community-based salt.

Short and Easy Production Process. A community-based salt production in the Palu is done by a simple method and in general through the production process is quite brief, lasting only occurred for 5 to 10 days. It is strongly supported and determined by the weather conditions at the time of the production takes place. Weather in Palu in general and in particular in Palu bay is warm throughout the year with maximum solar radiation which has implications for the production, thus it is helping the result of a community-based salt production.

New Technology Receptiveness. Salting activities in the Palu bay is an activity that has lasted a long time and sustained forwarded by the land owners to produce the salt pond as a source of family income. The production process itself still using methods that is taught and passed down by their parents who once also was the producer of salt. Maximizing the salting activities, respondents generally expect the application of new technologies, which in the future will result higher in production with better quality as well.

\section{Weaknesses Include:}

Limited Fund. According to Sutrisno (2006), a capital fund is one of the internal factors that are important in business execution. Capital financing in business management activities can be derived from their own or can be a loan from other parties. Based on the results of interviews with respondents note that the salt farmers have limited capital funds in supporting the production. Limited capital financing of the salt farmers have been a weakness or debilitating factor in increasing production. Nursaulah (2013) states that the salt farmers basically very well need a fund cash injection in the form of direct financing or loan money as an initial investment. Community-based salt business requires substantial fund capital to generate high revenue.

Traditional Production Techniques. The process of salt production in Palu bay in general are still performed traditionally and follow the method that has been handed down by those who first did the salt business which is still poorly innovated. Production techniques are rudimentary and lack of the application of new technologies, as well as additional treatment or innovations that able to increase the production of salt farmers is a weakness that influentially in improving the production at Talise village. According to Marzuki et al. (2014), According to Marzuki et al. (2014), with the salt making process which is done traditionally, the use of traditional tools that are simple to produce the salt is a technical aspect.

Un-optimal Institution. Institutional in salting activities is very important, the 
existence of an institution are going to become a shared container for the community to develop business and to solve problems. According to Sukesi (2011), the weakness in capital aspect also become input or suggestions for institutional improvement. Based on the interviews with respondents, cooperative container is the basic things that required to ensure a stable price of salt. The stability of salt price may reduce the role of middlemen in determining the price of salt from community-based salt production. Institutions that do not run well on salting business can be a weakness which resulting a lower production income received by the salt farmers.

Low Quality Production Result. The low quality of salt can be seen visually by the color of the resulting salt. The salt resulted from the industry in Palu bay isn't looks brightly white. The condition caused by a mixture of soil and salt generated during harvesting process as well as the quality of the raw materials used. Najib Moch (2007), suggests that the minor quality of the community-based salt caused by the pollutant quality, process technology process, as well as an early harvest time.

The low quality of salt also seen from the grain of salt that produced. Based on the respondent Interview sretrieved that the salt that could not last longer and easily destroyed engendered by the small grain of salt produced. Where as the farmers wish to keep the salt longer to gain higher profit during the rainy season where the price of salt is more expensive.

Based on interviews and discussions, each internal environmental factors that influence the improvement of the community-based salt production in the Gulf of Palu, further evaluated as presented in Table 1.

Based on the Internal analysis (IFAS) in Table 1 note that Strength has a value of 1.68 and weakness1.14. It shows that the weakness of thecommunity-based salt activities smaller than its powers.

\section{External Strategy Evaluation Factors (EFAS)}

\section{Opportunities :}

Soil and Climate Support. Salt production activities are highly influenced by several factors such as soil, water and climate. Suitable soil conditions isa tool that can increase the production of salt. Salt production suitable to carried out in warm/hot, dry and sunny temperature area. The salt making process in low temperatures and cold area was incompatible. These requirements are also fully compatible with the temperature conditions in Palu. The climate in Palu tend to be sunny throughout the year which made it's suitable as salt production area.

Governments Support. In order for the salt industry to gain success, government's support is surely an important factors. Some government policy and activities that support the salting process in Palu bay are by helping and providing as well as improving the facilities and infrastructure to support the production. Salt farmers in Palu bay receive assistance and support from the government through the Ministry of Maritime Affairs and Fisheries in the form of financial fund fordike and water drain repairing and other facilities.

Technological Innovation. To increase and improve both quality and production the Salt business in Gulf of Palu which maintained traditionally need innovation and technology. The conditions isnecessary in order to increase the production, through the use of technology and innovation activities of the communitybased salt production. The appropriate application of technology and innovation improve competitiveness. The need of innovation and new technology in business is essential, it is an opportunity to increase the production of community-based salt people.

Fluent Accessibility. According to Darmapuspita (2013), accessibility is defined as the level of convenience to achieve or obtain goods and services needed. Salting 
activities in Palu Bay is located near to urban areas, it is becoming one of the main things that is very supportive thus the marketing activity from industrial products current and easy. The Smoothness and ease of access to the distribution of industrial products also allows consumers to obtain the required salt easily. Easy and smooth access in distributing process it's not only because the salting area located in the urban areas but also supported by supported by the smooth transport and road access to the industrial area in Palu bay.

\section{Threats:}

Coastal Reclamation. Reclamation of the Gulf region to bring more negative impact on the people's business continuity salt. The direct impact is felt by the salt farmers is the disruption of the major waterways of the sea to the salting plots, besides that reclamation will further the distance between the source of raw material to the salt ponds. Sustainability and expansion of the reclamation is a huge threat for the community-based salt business in Palu Bay.

Middleman Price Stipulation. Middleman existence is a common thing, especially in a community-based industry. Through discussions and interviews with salt farmers as respondents revealed that the salt farmers set the price of the salt also influenced by the middlemen. The salt farmers usually produce the salt continuously throughout the year to meet the daily needs, such a condition forcing the farmers to sell their product with the prices that determined by middlemen, especially when the production is abundant.

Raw Materials (Sea Water) Contamination. The conditions of the abundant raw materials and the location of salting adjacent to the settlement allows the risk of contamination of raw material which must threaten salt production activities of the people, especially the salt production activities are still using simple and traditional methods. This includes the provision and compliance processes from raw materials that do not involve any evolving technology. a decrease in the quality of sea water used as raw material and the condition of the salt business easily polluted waters is the impact of salting production site is in Palu bay area adjacent to urban areas. The sea water is susceptible mixed with household waste and then directly channeled into the pond without any special treatment or involvement of additional technologies to filter the water, polluted sea water is very threatening this community-based salt production.

Private Institution Partnership. One of the main efforts to overcome their limited capital and limited range of markets for farmers is to build partnerships. Partnership is done with the aim to develop the technology in the production process and marketing based on the principlenof expediency in the form of mutually beneficial cooperation. Viewed from salinity state conditions which are in the bay of Palu and the results ofninterviews with salt farmers around the bay of Palu was found that the partnership has not been formed, whereas partnerships with employers or private agencies is essential for the production and distribution process salting.

Based on the interviews with the respondents, obtained some respectively external factors of the environment, the following factors are presented in Table 2.

Based on analysis of external factors (EFAS) in Table 2, it is stated that Opportunities factors has a value of 1.35, while the threat factors has a value of 1.24. The data explains that the opportunities still outweigh the threat factor with a ratio of $52.12 \%$ vs. $47.88 \%$. Thus it can be stated that the salting industry in Palu Bay still has good prospects for enhancement production.

Based on data from Table 3, the acquisition value score in SO Strategies (Strength-Opportunities) is equal to 3.03; WO Strategy (weaknesses-Opportunities) of 2.49; WT Strategy (weaknesses-Threats) of 2.92 and ST Strategies (Strength-Threats) 
of 2.38. The highest value of the score calculations are in the first quadrant region with SO strategy that is equal to 3.03 (Strength-Opportunities). This quadrant describes a favorable situation to increase the production because of the ability and opportunities that can be exploited. Based on IFAS and EFAS matrix as well as the SWOT analysis diagram, strategies can be assumed. It is seen in SWOT Analysis Results matrix that presented in Table 4.

Based on the scores and results of the evaluation of internal and external factors which have been obtained, it is known that the highest score is in quadrant I, which supports an aggressive strategy that is with a score of 2.95. Thus, strategies that can be implemented are as many as three alternative strategies, namely:

a). Maximizing production by utilizing the resources available. Activities that can be done is to seek the adoption of a better production technologies, a more efficient and leverage technology. It can also be done through the utilization of the resources that have been provided, for example, the raw materials that are abundant along with the experience owned by the farmers which is also becomes a supporting factor in maximizing the production both in quality and quantity. These efforts are also supported by land and climate conditions in Palu bay to be able to produce salt throughout the whole year simultaneously with Government support through the facilitation of production and improvement of infrastructure and guidance or counseling assistance.

b). Improving human resources or the ability of the salt farmers are better accompanied by the adoption of an appropriate technological innovations. Improve the human resource and farmers capacity can be done through some training or technical assistance with a variety of counseling, so that the farmers can adopt a better system, innovated technology as well as the production techniques than that have been done so far. A better understanding of how to manage the salt business of can be obtained by the farmers through a human resources quality enhancement. Technically, some action to do are (1) a workshop or technical training of methods and technologies that can be used in salt production. (2) to participated in the internship or comparative study to salt production centers which has a far more developed technology and have used the right technology to produce salt with much better quality.

c). Marketing management capacity Improvement and broader partnership development. Such as strategy implemented as an effort to optimize the use of the opportunities along with a growing market demand and to absorb the production profit maximally. Along with the research that has been done by Heriansyah and Fathuddin (2014), which stated that required an increase of the capacity of marketing management to make optimum use of the various opportunities in the community-based salt business to face the era of market competition in the future. Specific training relating to business management are very important, it is an attempt to instill a business-oriented entrepreneurial spirit and to improve the ability of the salt farmers.

Quantitative Analysis Strategic Planning Matrix (QSPM). Quantitative Strategic Planning Matrix (QSPM) is a tool that allows the strategists to evaluate an alternative strategies objectively, based on the external and internal success determined factors has been identified previously. QSPM determine the relative attractiveness of various strategies developed in the matching stage (Richard et al, 2012; Rauf et al., 2015). According to Husein Umar (2008), based on the internalexternal key success factors has been identified previously. QSPM is a recommended tool for the strategists to evaluate the alternative options strategies objectively. 
Table 1. Internal Strategy Evaluation Factors (IFAS) Community-Based Salt Production Enhancement

\begin{tabular}{lcccc}
\hline \multicolumn{1}{c}{ Internal Factors } & $\begin{array}{c}\text { Weight } \\
(\mathrm{a})\end{array}$ & $\begin{array}{c}\text { Rating } \\
(\mathrm{b})\end{array}$ & $\begin{array}{c}\text { Score } \\
(\mathrm{axb})\end{array}$ & $\begin{array}{c}\text { Description } \\
(\%)\end{array}$ \\
\hline A. Strengths & & & & \\
1. $\quad$ Experienced Salt Farmer & 0.13 & 3 & 0.39 & \\
2. Abundant Raw Materials Availability & 0.17 & 4 & 0.68 & \\
3. New Technology Receptiveness & 0.11 & 2 & 0.22 & \\
4. Short and Easy Production Process & 0.13 & 3 & 0.39 & \\
\hline$\quad$ Total A & 0.54 & 12 & 1.68 & $59.57 \%$ \\
\hline$\quad$ B. Weakness & & & & \\
1. Limited Fund & 0.12 & 3 & 0.36 & \\
3. Traditional Production Techniques & 0.11 & 2 & 0.22 & \\
3. Un Optimal Institution & 0.10 & 2 & 0.20 & \\
4. Low Quality Products & 0.12 & 3 & 0.36 & \\
$\quad$ Total B & 0.46 & 10 & 1.14 & $40.43 \%$ \\
\hline$\quad$ Total A + B & 1.00 & 22 & 2.82 & $100.00 \%$ \\
\hline
\end{tabular}

Source: Processed Primary Data, 2016.

Table 2. External Strategies Evaluation Factor (EFAS) Community-Based Salt Production Enhancement in Sub-District Mantikulore, Palu

\begin{tabular}{|c|c|c|c|c|}
\hline External Factors & $\begin{array}{l}\text { Weight } \\
\text { (a) }\end{array}$ & $\begin{array}{l}\text { Rating } \\
\text { (b) }\end{array}$ & $\begin{array}{l}\text { Weight } \\
\text { (axb) }\end{array}$ & $\begin{array}{c}\text { Description } \\
(\%)\end{array}$ \\
\hline \multicolumn{5}{|l|}{ Opportunities } \\
\hline 1. Land and Climate Support & 0.16 & 3 & 0.48 & \multirow{4}{*}{0.24} \\
\hline 2. Government Support & 0.12 & 2 & & \\
\hline 3. Expedite Accessibility & 0.13 & 3 & 0.39 & \\
\hline 4. Technological Innovation & 0.12 & 2 & 0,24 & \\
\hline Amount A & 0.53 & 10 & 1.35 & 52.12 \\
\hline \multicolumn{5}{|l|}{ Threats } \\
\hline 1. Coastal Reclamation & 0.07 & 1 & 0.07 & \\
\hline 2. Middleman Price Stipulation & 0.13 & 3 & 0.39 & \\
\hline 3. Raw Materials Pollution & 0.13 & 3 & 0.39 & \\
\hline 4. Private Institution Partnership & 0.13 & 3 & 0.39 & \\
\hline Amount B & 0.47 & 10 & 1.24 & 47.88 \\
\hline Total A + B & 1.00 & 20 & 2.59 & 100.00 \\
\hline
\end{tabular}

Source: Primary Data Processed, 2016.

Table 3. IFAS and EFAS Enhancement Production Matrix in Community-Based Salt at Palu Bay

\begin{tabular}{ccc}
\hline EFAS & Strength (S) & Weakness (W) \\
\hline Opportunities (O) & Strategy (SO) & Strategy \\
& & $($ WO) $1.68+1.35=3.03$ \\
Threats (T) & Strategy (ST) & $1.14+$ \\
& $1.24+=2.921 .14+1.24=$ & Strategy (WT) \\
& 2.38 & 1.68 \\
\hline
\end{tabular}

Source: Primary Data Processed, 2016. 
Table 4. SWOT Analysis Results Matrix of Community-Based Salt Enhancement Production

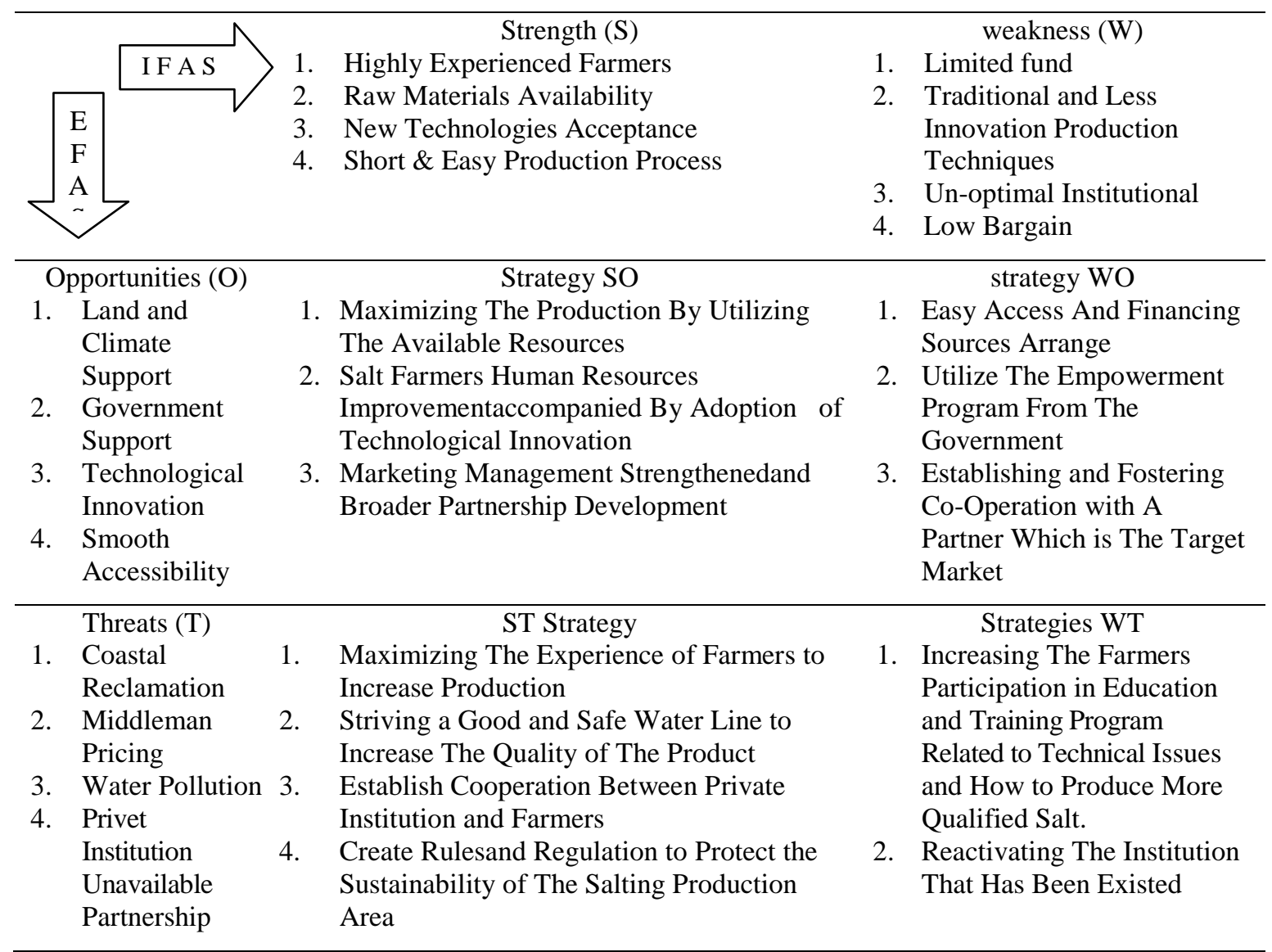

Source: Primary Data Processed, 2016.

QSPM matrix is made based on the internal and external factors as well as the SWOT matrix. In QSPM Matrix contained the value of AS matrix (Attractiveness Score) and the value of TAS. The value of the AS shows the attractiveness of each strategy against the key factors that are owned. AS Values obtained through a questionnaire addressed to the respondents currently on independent discussions. TAS value is the result of multiplying the average weighted of AS value owned from the strategic key factor. Based on QSPM analysis, the results from QSPM research reveal that the priority programs chosen from the S-O strategy with Total Attractiveness Score (TAS) obtained show that the strategy can be prioritized or considered as the best strategy in an effort to increase the production of salt farmers in Palu Bay. Calculations with QSPM matrix can be seen in Annex 1.
QSPM Analysis indicates that the most suitable and perfect program to increase the production of communitybased salt in Palu Bay is the $2^{\text {nd }}$ program which is to "Increase The Human Resources of The Salt Farmers Accompanied with The Adoption of Some Prominent Methods and Appropriate Technological Innovation" with the largest total value of attractiveness (TAS ), equal to 6.154 .

\section{CONCLUSION}

The strategy used to increase the production of salt in the Gulf of Palu is the strategy of the S-O (StrengthsOpportunities), thus the right program to do is (A) maximize the production by utilizing the resources already available, (B) increase the farmers human resources as well as adopting appropriate technology innovation system, (C) an increase in capacity regarding marketing management 
and establish a broader network of partnership. Based on the analysis we concluded that the S-O strategy of QSPM (Strengths- Opportunities) is the most suitable strategy. Of the three types of programs in order to increase production of community-based salt in Palu bay, the 2nd program is the most recommended one, which is to "improve the knowledge and capability of the salt farmers, accompanied by the adoption of an appropriate technology innovation system".
Based on the research results suggested that (1) The local government in taking a policy would not ignore the existence and continuity of salting area as well as to prevent land functional shift, which incidentally a major threatens of the salt production resource. (2) to increase farmers human resources through some training, field trip, internships or further technical workshop related to the salting techniques.

\section{REFERENCES}

Darmapuspita B. 2013. Pengaruh Aksesibilitas Terhadap Karakteristik Sosial Ekonomi Masyarakat Pedesaan Kecamatan Bumijaya Kabupaten Tegal. J. Wilayah dan Lingkungan 1 (1): 49 - 66.

Dinas Pertanian, Kehutanan dan Kelautan Kota Palu, 2015. Laporan Tahunan Pemberdayaan Usaha Garam Rakyat Kota Palu. Dinas Pertanian Kehutanan dan Kelautan Kota Palu. Palu.

Heriansah dan Fathuddin. 2014. Analisis Tataniaga Garam untuk Pengembangan Usaha Garam Rakyat di Kabupaten Pangkep. J. Balik Diwa 5 (2): 1 - 9.

Kurniasari Nendah. 2014. Membangun Sinergitas Antar Pelaku dalam Pemberdayaan Masyarakat Perikanan Melalui Iptek Mina Bisnis (Studi Kasus Pelaksanaan Klinik Iptek Mina Bisnis di Kabupaten Subang). Buletin Riset Sosek Kelautan dan Perikanan 9 (2) : 35 - 39.

Kusumaningrum Arta. 2013. Kebijakan Pembangunan dalam Pengentasan Kemiskinan Masyarakat Pesisir (Studi Kasus pada Masyarakat Pesisir di Kabupaten Purworejo, Jawa Tengah). J. Agriekonomika 2 (1): $13-26$.

Marzuki, Indra dan Sofyan. 2014. Prospek Industri Garam Tradisional Ditinjau dari Aspek Teknis Aspek Finansial dan Aspek Pasar di Kabupaten Aceh Besar. J. Agrisep Universitas Syiah Kuala Banda Aceh 15 (2) : 1 - 9.

Nadjib Moch. 2007. Analisis Spatial Produktivitas Garam di Pulau Jawa dan Madura. J. Sumberdaya Perairan 2 (8): $1-7$.

Nursaulah. 2013. Evaluasi Kelayakan Usaha Garam Rakyat Berpola Subsistem dalam Rangka Pembangunan Ekonomi di Kawasan Pesisir. J. Ilmiah Universitas Brawijaya Malang 1 (1): 1 - 24.

Rahman Amril, Sapta Raharja, Darwin Kadarisman. 2014. Evaluasi Kinerja Usaha Petambak Garam Rakyat di Kabupaten Bima Nusa Tenggara Barat. J. Manajemen IKM 9 (1): 106 - 118.

Rauf R.A. Saiful Darman, Atik Andriana. 2015. Pengembangan Usahatani Bawang Merah Varietas Lembah Palu dan Strategi Analisis SWOT. J. Agriekonomika 4 (2): 245-257.

Richard.A.de FRETES, Purnomo. B. Santoso, Rudy Soenoko, Murty Astuti, 2012. Strategi Perencanaan dan Pengembangan Industri Pariwisata dengan Menggunakan Metode Swot dan QSPM (Studi Kasus Kecamatan Leitimur Selatan Kota Ambon). J. Rekayasa Mesin 4 (2):109-118.

Sukesi. 2011. Analisis Perilaku Masyarakat Petambak Garam Terhadap Hasil Usaha di Kota Pasuruan. J. Mitra Ekonomi dan Manajemen Bisnis 2 (2): 225 - 244.

Sutrisno.2006. Analisis Lingkungan Internal dan Eksternal Peningkatan Produksi Garam Rakyat (Studi di Kecamatan Batangan Kabupaten Pati). J. Litbang Kabupaten Pati 3 (1): 1 - 14.

Umar Husein. 2008. Strategic Managemen in Action. Gramedia Pustaka Utama. Jakarta

Widiarto S.B, Hubelas. M dan Sumantadinata. K. 2013. Efektivitas Program Pemberdayaan Usaha Garam Rakyat di Desa Losarang, Indramayu. J. IPB Manajemen IKM 8 (2): 1 - 11. 
Appendix 1. QSPM Priority Analysis Result - Community-Based Salt Enhancement Strategy

\begin{tabular}{|c|c|c|c|c|}
\hline Factor Strategy & Weights & $\begin{array}{c}\text { Strategy } 1 \\
\text { TAS }\end{array}$ & Strategy 2 & $\begin{array}{c}\text { Strategy } 3 \\
\text { TAS }\end{array}$ \\
\hline \multicolumn{5}{|l|}{ Strength } \\
\hline 1 Experienced Salt Farmer & 0.13 & 0.380 & 0.478 & 0.322 \\
\hline Raw Materials availability & 0.17 & 0.455 & 0.578 & 0.485 \\
\hline New Technology acceptance & 0.11 & 0.352 & 0.322 & 0.187 \\
\hline 4 Short \& Easy Production Process & 0.13 & 0.465 & 0.413 & 0.364 \\
\hline \multicolumn{5}{|l|}{ Weakness } \\
\hline 1. $\quad$ Limited Fund & 0.12 & 0.300 & 0.336 & 0.417 \\
\hline $\begin{array}{l}\text { Outdated \& Traditional Production } \\
\text { Techniques }\end{array}$ & 0.11 & 0.286 & 0.374 & 0.360 \\
\hline 3. Un-Optimal Institutional & 0.10 & 0.270 & 0.368 & 0.273 \\
\hline $4 \quad$ Low Quality Product & 0.12 & 0.255 & 0.261 & 0.348 \\
\hline \multicolumn{5}{|l|}{ Opportunities } \\
\hline 1. Land and Climate Support & 0.16 & 0.540 & 0.496 & 0.452 \\
\hline 2. Government Support & 0.12 & 0.387 & 0.423 & 0.360 \\
\hline 3. Fluent Accessibility & 0.13 & 0.335 & 0.374 & 0.439 \\
\hline 4. Technological Innovation & 0.12 & 0.411 & 0.435 & 0.366 \\
\hline \multicolumn{5}{|l|}{ Threats } \\
\hline 1. Coastal Reclamation & 0.07 & 0.149 & 0.128 & 0.168 \\
\hline 2. $\quad$ Middleman Pricing & 0.13 & 0.315 & 0.419 & 0.400 \\
\hline 3. Raw Materials Pollution (Sea Water) & 0.13 & 0.254 & 0.436 & 0.445 \\
\hline $\begin{array}{l}\text { Unavailability of Partnership ( Private } \\
\text { Institution ) }\end{array}$ & 0.13 & 0.215 & 0.315 & 0.309 \\
\hline Total Fascination Value & & 5.368 & 6.154 & 5.694 \\
\hline
\end{tabular}

Source: Primary Data Processed, 2016. 